\title{
Intestinal parasites in two indigenous ethnic groups in northwestern Amazonia
}

\author{
Raylene Andrade OLIVEIRA ${ }^{1}$, Rodrigo GURGEL-GONÇALVES ${ }^{1 *}$, Eleuza Rodrigues MACHADO ${ }^{1,2}$ \\ 1 Universidade de Brasília, Faculdade de Medicina, Laboratório de Parasitologia Médica e Biologia de Vetores, Brasília, Distrito Federal, Brasil. \\ 2 Faculdade Anhanguera de Brasília, Unidade de Taguatinga, Brasília, Distrito Federal, Brasil. \\ * Corresponding author: gurgelrg@hotmail.com
}

\begin{abstract}
Approximately $90 \%$ of the population in the northwestern Amazonia is composed of indigenous people and their healthcare is still a challenge. The objective of this study was to determine the frequency of parasites in two indigenous ethnic groups (Baré and Baniwa) in northwestern Amazonia. Stool samples from 270 individuals (199 Baniwa and 71 Baré) were analyzed using Richie's method and the spontaneous sedimentation method. Statistical differences among the proportions of infected individuals based on gender, age, and ethnicity were determined. All individuals were infected by protozoans or helminths. The most frequent parasites in the indigenous people were Ascaris lumbricoides (73\%), Entamoeba spp. (53\%), and Giardia intestinalis (48\%). Protozoan parasites were more common among children aged 0-12 years; however, the frequency of helminths, such as hookworms and A. lumbricoides, was higher in adults. There were no significant differences in parasite frequencies between different genders or ethnic groups. Mixed infections by two or more protozoan and/or helminth species were detected in $96 \%$ of individuals. One individual was infected by 14 species. A high frequency of intestinal parasites was found in Baré and Baniwa ethnic groups. Improvements to infrastructure and health education programs are required to reduce risk of infection by intestinal parasites.
\end{abstract}

KEYWORDS: Indigenous Population, Parasitic Diseases, Stool samples, Amazon region.

\section{Parasitos intestinais em dois grupos indígenas no noroeste da Amazônia}

\section{RESUMO}

Aproximadamente $90 \%$ da população no noroeste da Amazônia é composta de grupos indígenas e o acesso deles aos serviços de saúde ainda é um desafio. O objetivo deste estudo foi determinar a frequência de parasitos em dois grupos indígenas (Baré e Baniwa) no noroeste da Amazônia. Amostras de fezes de 270 indivíduos (199 Baniwa e 71 Baré) foram analisadas pelos métodos de Richie e sedimentação espontânea. Foram determinadas diferenças estatísticas entre as proporçôes de indivíduos infectados com base no sexo, idade e etnia. Todos os indivíduos estavam infectados por protozoários ou helmintos. Os parasitos mais frequentes nos índios foram Ascaris lumbricoides (73\%), Entamoeba spp. (53\%), e Giardia intestinalis (48\%). Protozoários parasitos foram mais comuns entre as crianças com idade entre 0-12 anos; no entanto, a frequência de ancilostomídeos e $A$. lumbricoides foi maior em adultos. Não houve diferenças significativas nas frequências de parasitos entre os diferentes sexos ou grupos étnicos. Infecçóes mistas por duas ou mais espécies de protozoários e/ou helmintos foram detectadas em 96\% dos indivíduos. Um indivíduo estava infectado por 14 espécies. Uma alta frequência de parasitos intestinais foi encontrada em indígenas dos grupos Baré e Baniwa. Melhorias dos programas de infra-estrutura e educação em saúde são necessárias para reduzir o risco de infecção por parasitos intestinais.

PALAVRAS-CHAVE: Populaçôes indígenas, doenças parasitárias, amostras fecais, Região Amazônica. 


\section{INTRODUCTION}

Most of indigenous people worldwide live poor health conditions, which are associated with malnutrition, overcrowding, poor hygiene, and environmental contamination (Stephens et al. 2005; Gracey and King 2009). In Brazil, many indigenous communities lack basic sanitation (Coimbra 2014). This situation makes it easier for various parasitic diseases to spread (Santos and Coimbra 2005).

High frequencies of intestinal parasites have been observed in indigenous peoples throughout Brazil, such as Xavante (Santos et al. 1995), Hüpda (Bóia et al. 2009), Kaingáng (Moura et al. 2010), Maxakali (Assis et al. 2013), Terena (Neres-Norberg et al. 2014), and other ethnic groups in Amazonia (Martins et al. 2015). The process of economic expansion in the Brazilian Amazon region has been accompanied by a significant deterioration in the health conditions of the indigenous communities, and a strong presence of infectious and parasitic diseases has historically been seen (Coimbra 2014). In the Brazilian state of Amazonas, studies have shown a very high prevalence of helminths in indigenous communities (Lawrence et al. 1983; Genaro and Ferraroni 1984). This situation was found to be persistent in more recent studies in the region (Rios et al. 2007; EscobarPardo et al. 2010; Santos et al. 2010; Martins et al. 2015).

In the Negro River region, which is located in northwestern Amazonia, approximately $90 \%$ of the population is composed of indigenous ethnic groups. Few urban centers are located in this region, including the municipalities of Barcelos, Santa Isabel do Rio Negro, and São Gabriel da Cachoeira. The geographic location of these communities hinders access to public services, and indigenous healthcare is still a challenge for local authorities. The prevalence of Ascaris lumbricoides and hookworms is very high (45-95\%), and protozoans such as Giardia intestinalis and Entamoeba spp. are also frequent in indigenous people from this region (Lawrence et al. 1983; Genaro and Ferraroni 1984; Rios et al. 2007; Escobar-Pardo et al. 2010; Santos et al. 2010; Martins et al. 2015). However, little is known about the occurrence of parasites among different ethnic groups in Amazonia. Thus, the aim of the research was to determine the frequency of protozoans and intestinal helminths in indigenous communities represented by two ethnic groups in the municipality of São Gabriel da Cachoeira, in the state of Amazonas, Brazil, in 2014.

\section{MATERIALS AND METHODS}

The current research represents a cross-sectional study with a non-probability sample of indigenous people from the communities of Boa Vista $\left(0^{\circ} 27^{\prime} \mathrm{N}, 67^{\circ} 19^{\prime} \mathrm{W}\right)$ and Assunçáo do Içana $\left(01^{\circ} 03^{\prime} \mathrm{N}, 67^{\circ} 36^{\prime} \mathrm{W}\right)$, which are located on the upper Rio Negro within the municipality of São
Gabriel da Cachoeira in the Brazilian state of Amazonas. This municipality is located in the extreme northwest of the country; it borders Venezuela and Colombia to the north and the Brazilian municipality of Santa Isabel do Rio Negro to the south and to the east.

These communities are inhabited by people from various ethnic groups (e.g. Baré, Tukano, Baniwa, Wanano, and Tariana). Approximately 100 families and 500 people live there in total. The information on the number of inhabitants and households was obtained from data from the Special Indigenous Sanitary District of São Gabriel da Cachoeira. Indigenous people representing two ethnical groups (Baré and Baniwa) were sampled.

The communities were selected because of their low socioeconomic levels and their difficulty in accessing healthcare services. Both children and adults in the families who agreed to participate in the study and who signed the authorization form were included. The study was approved by the Ethics Committee on Human Research of the University of Brasília (No. 042342/2012). The results of parasitological examinations were given to each individual, and they were referred to medical health assistance program to receive specific treatment. Before the stool collection process, a presentation was carried out in the communities to explain the purpose of the research and the methods. This activity was supported by an indigenous healthcare agent who translated the presentation and the authorization forms into the Nheengatu language. No remuneration was given to participants.

Two stool samples per individual were collected in 80-g plastic bottles between March and April 2014. The families were instructed on how to collect the stool, which was delivered to the researchers in communities. The maximum range between each collection was 3 days. The samples were identified, preserved in $10 \%$ formaldehyde, stored in polystyrene boxes, and transported to the Laboratory of Medical Parasitology and Vector Biology of the University of Brasília where they were processed.

The parasitological diagnosis was performed using Richie's method (Ritchie 1948) and the spontaneous sedimentation method (Hoffmann et al. 1934). For each sample, eight microscope slides were stained with Lugol and examined using an optical microscope at 400x magnification for the visualization and identification of parasites, as described elsewhere (Machado et al. 1998). Chi-square or Fisher's exact tests were applied to verify statistical differences between the proportions of infected individuals according to gender, age, and ethnicity. Statistically significant differences were considered when $p<0.01$. Tests were performed using the statistical package Graphpad (GraphPad Software, Inc. California, USA). 


\section{RESULTS}

In total, stool samples from 199 individuals of the Baniwa ethnic group (109 women and 90 men) and 71 individuals of the Baré ethnic group (34 women and 37 men) were analyzed. Ninety-one individuals (34\%) were between 0 and 12 years of age. All individuals were infected by protozoans or helminths. There were no significant differences in parasite frequencies between different genders or ethnic groups.
Among the helminths, A. lumbricoides was the most common species, followed by hookworms. Entamoeba spp. and Giardia intestinalis were the most frequent protozoan species (Figure 1). Giardia intestinalis and Entamoeba spp. were more common among children aged 0-12 years. However, the frequency of helminths, such as hookworms and $A$. lumbricoides, was higher in adults (Figure 2). Other parasites (Balantidium coli, Enterobius vermicularis, Hymenolepis spp.,
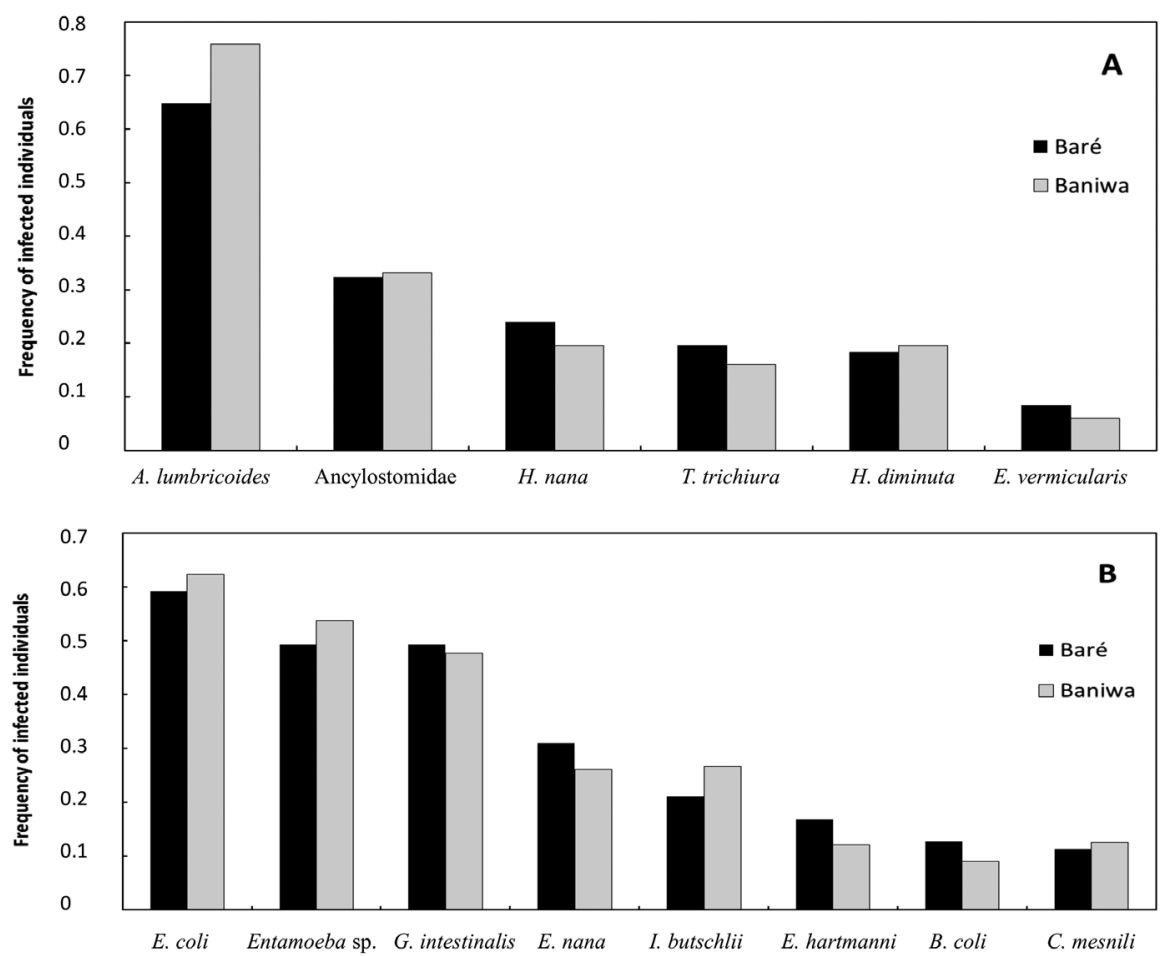

Figure 1. Distribution of helminths $(A)$ and protozoans (B) found in individuals from two ethnic groups (Baré and Baniwa) in the municipality of São Gabriel da Cachoeira, Amazonas State, Brazil, in 2014.

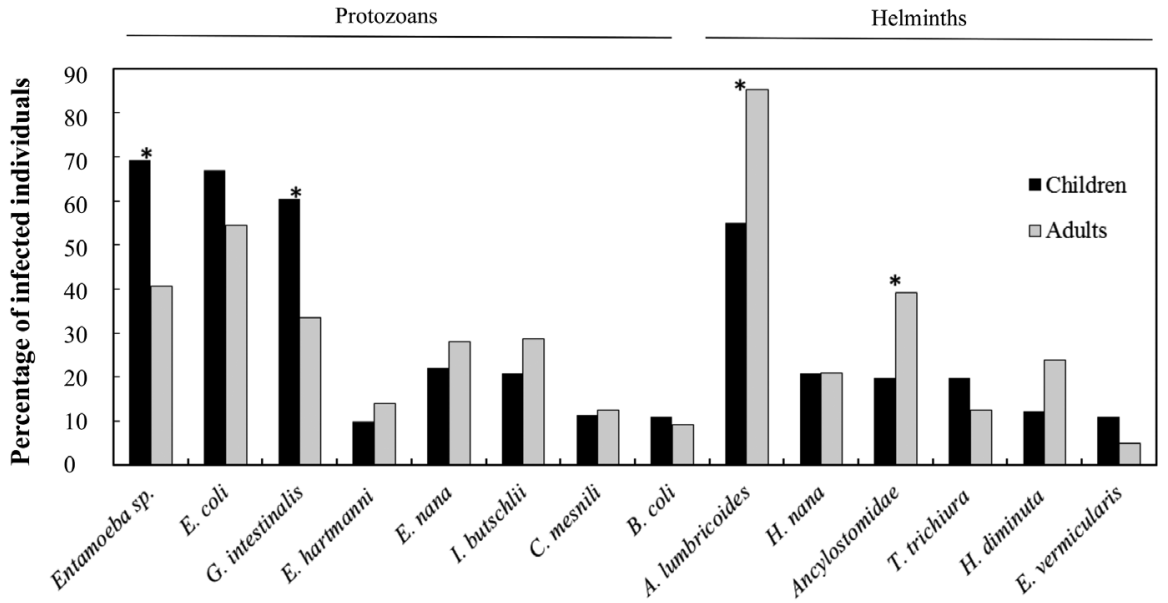

Figure 2. Helminth and protozoan distribution in adults and children from indigenous communities in the municipality of São Gabriel da Cachoeira, Amazonas State, Brazil, 2014. * significant differences among the groups $(p<0.01)$. 


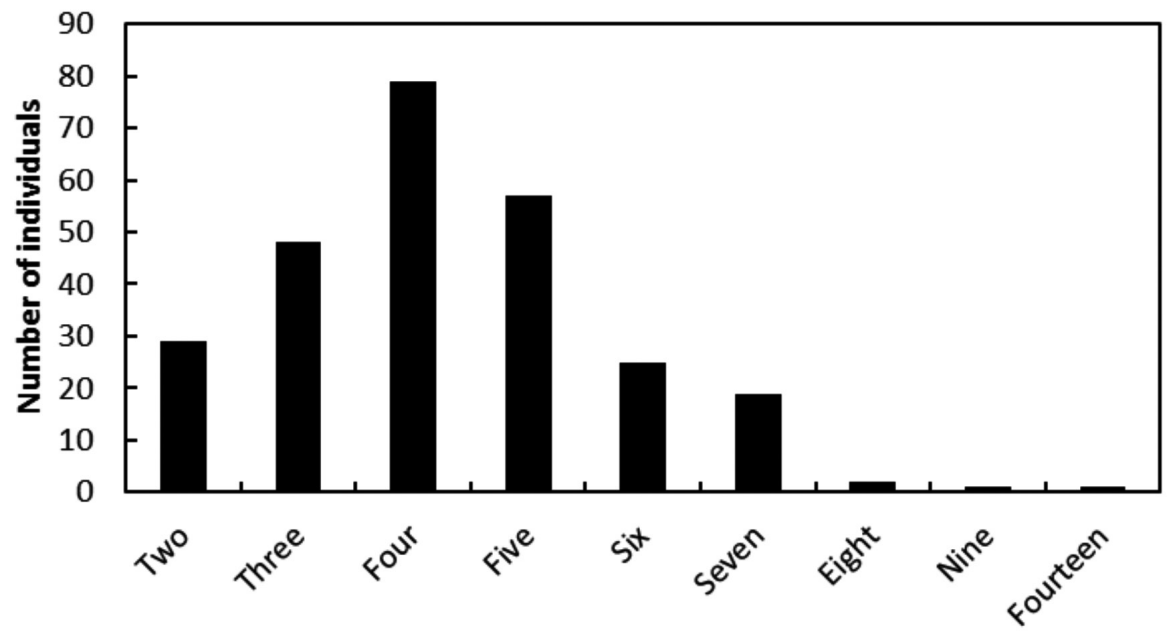

Number of species of protozoa or helminths

Figure 3. Mixed infections by two or more protozoan and/or helminth species in individuals from two indigenous communities in the municipality of São Gabriel da Cachoeira, Amazonas State, Brazil, 2014.

and Trichuris trichiura) and commensals (Endolimax nana, Iodamoeba butschlii, Entamoeba hartmanni, and Chilomastix mesnili) were also detected (Figure 1).

Two hundred and sixty individuals (96\%) had mixed infections by two or more protozoan and/or helminth species. Most mixed infections were by three to five species, which were most commonly $A$. lumbricoides and $G$. intestinalis, $A$. lumbricoides and E. coli, or E. coli and G. intestinalis. One 10-year-old-girl was infected by 14 species (Figure 3).

\section{DISCUSSION}

In Brazil, high frequencies of intestinal parasites have been observed in different regions and ethnic groups, particularly in Amazonia (Santos and Coimbra 2005; Bóia et al. 2009; Martins et al. 2015). In the current study, higher frequencies of parasites in Baniwa and Baré indigenous groups were found when results were compared to those reported by Rios et al. (2007) in their analysis of the Tariano and Tukano ethnic groups from the same region. However, no differences were observed in frequency of parasites between the Baniwa and Baré ethnic groups; this similarity probably occurred because these communities share the same environmental conditions that favor transmission.

The frequency of $A$. lumbricoides among the Baniwa ethnic group (76\%) was higher than that observed in other indigenous groups in the state of Amazonia (Genaro and Ferraroni 1984; Rios et al. 2007; Martins et al. 2015). Although the frequency of hookworms in the present study (33\%) was higher than that observed by Rios et al. (2007) $(5 \%)$, it did not reach values as high as those reported by Genaro and Ferraroni (1984) (96\%). The same pattern was observed in the case of infections by T. trichiura. Entamoeba species were found to be the most common protozoans in these communities, a result which was similar to findings from other studies (Genaro and Ferraroni 1984; Miranda et al. 1998; Rios et al. 2007; Martins et al. 2015). The differences in prevalence found in these studies may be due to the parasitological methods employed, to different sample sizes, or to the testing of ethnic groups.

The high prevalence of parasitic diseases in indigenous people may be associated with poor living conditions and inadequate healthcare services (Gracey and King 2009). Some behaviors favor the transmission of parasites among indigenous peoples, including defecation around the home and most of the population's lack of shoes. Environmental factors such as soil moisture and high temperatures in the Amazon region favor the development and maintenance of infective stages of these parasites (Coimbra 2014). In addition, basic sanitation indicators are poor in indigenous communities: only $0.6 \%$ of indigenous households in the northern region of Brazil have indoor bathrooms. Moreover, drinking water is not properly treated. These examples show that indigenous villages generally lack minimally adequate healthcare infrastructure in Brazil (Coimbra 2014).

In this study, no correlation was found between gender and parasitism, a result which agrees with other studies that also compared the frequency of parasites between indigenous peoples of different genders (Miranda et al. 1998; Rios et al. 2007). A higher frequency of intestinal parasites in children has been previously observed in indigenous communities (Genaro and Ferraroni 1984; Miranda et al. 1998). In the current study, however, A. lumbricoides was found to be more 
frequent in adults. This result was unexpected, because other studies on indigenous and non-indigenous populations have reported $A$. lumbricoides to be more frequent in children due to their relatively poor hygiene and to immunological factors (Genaro and Ferraroni 1984; Miranda et al. 1998; O'Lorcain and Holland 2000).

Mixed infections by 3-5 species have been found to be very common in different communities. More than half of the Parakana indigenous population in the Brazilian state of Pará was also found to have two or more species of parasites (Miranda et al. 1998). Meanwhile, 33\% of the Nadëb-Maku population in the state of Amazonas was found to be infected by three species of parasites (Genaro and Ferraroni 1984). Multiple infections by helminth species during childhood can have a negative impact on the host's nutrition through various mechanisms, including chronic blood loss and malabsorption (Sayasone et al. 2015). These mechanisms can directly influence cognitive ability and motor performance and may also influence the growth process in children living in endemic areas (Weatherhead and Hotez 2015).

Though two parasitological techniques were used to detect intestinal protozoans and helminths, parasites commonly found in some indigenous populations were not detected, such as Cryptosporidium, Cyclospora cayetanensis (Borges et al. 2009), and Strongyloides stercoralis (Santos et al. 1995). Further analysis, including other methods of detection and staining of intestinal parasites (Clarke and Mclntyre 1996; Machado et al. 1998), may reveal the prevalence of these species in Baniwa and Bare communities and may strengthen our evidence of a high frequency of intestinal parasites among these indigenous populations. Additionally, the inclusion of other parasitological techniques could reveal occurrence of $B$. hominis, since other studies reported a high prevalence of B. hominis in indigenous communities in the Brazilian states of Pará (Borges et al. 2009) and Mato Grosso do Sul (Aguiar et al. 2007).

The high frequency of intestinal parasites in Baré and Baniwa communities indicate that primary and secondary healthcare assistance should be increased in the region immediately. Bathrooms, clean water supplies, and specific treatment of infections could be provided to prevent and control intestinal parasites in these regions (Gracey and King 2009). There is a need to develop healthcare programs in order to monitor parasite infection every six months as part of the specific treatment to reduce infection rates. Moreover, the Brazilian Ministry of Health recommends mass treatment of children in the municipalities with the highest prevalence rates to control geohelminthiasis (Martins et al. 2015). In the current study, a multidisciplinary intervention was carried out in the communities analyzed. It included health education lectures, new parasitological examinations, tests for hepatitis A, HIV, tuberculosis, and dental and medical care. The first stage of the intervention was followed by the distribution of medications according to the disease diagnosed. It was supported by the Municipal Health Secretariat of São Gabriel da Cachoeira, the local Military Hospital (Hospital de Guarnição do Exército), and the District Council of Indigenous Health (Conselho Distrital de Saúde Indígena). Finally, improvements in infrastructure and health education programs are also required to reduce environmental contamination, which will, in turn, reduce the risk of infection by intestinal parasites among indigenous people in northwestern Amazonia.

\section{CONCLUSIONS}

A high frequency of intestinal parasites was found in Baré and Baniwa ethnic groups. Ascaris lumbricoides was found at frequencies higher than $70 \%$, and mixed infections by 3-5 species were very common in the communities. Species distribution differed between children and adults. Helminths (A. lumbricoides and hookworms) were more common in adults, while protozoans (Entamoeba spp. and G. intestinalis) were more common in children.

\section{ACKNOWLEDGMENTS}

The authors would like to thank the team of healthcare professionals from the Municipal Health Secretariat of São Gabriel da Cachoeira, the Military Hospital, and District Council of Indigenous Health. RGG received fellowship from CNPq, Brazil.

\section{REFERENCES}

Aguiar, J.I.A.; Gonçalves, A.Q.; Sodré, F.C.; Pereira, S.R.; Bóia, M.N.; Lemos, E.R.S.; Daher, R.R. 2007. Intestinal protozoa and helminths among Terena Indians in the State of Mato Grosso do Sul: high prevalence of Blastocystis hominis. Revista da Sociedade Brasileira de Medicina Tropical, 40: 631-34.

Assis, E.M.; Oliveira, R.C.; Moreira, L.E.; Pena, J.L.; Rodrigues, L.C.; Machado-Coelho, G.L.L. 2013. Prevalência de parasitos intestinais na comunidade indígena Maxakali, Minas Gerais, Brasil. Cadernos de Saúde Pública, 29: 681-690.

Bóia, M.N.; Carvalho-Costa, F.A.; Sodré, F.C.; Porras-Pedroza, B.E.; Faria. E.C.; Magalhães, G.A., Silva, I.M. 2009. Tuberculosis and intestinal parasitism among indigenous people in the Brazilian Amazon region. Revista de Saude Publica, 43: 176-178.

Borges, J.D.; Alarcón, R.S.; Amato Neto, V.; Gakiya, E. 2009. Intestinal parasitosis in Indians of the Mapuera community (Oriximiná, State of Pará, Brazil): high prevalence of Blastocystis hominis and finding of Cryptosporidium sp. and Cyclospora cayetanensis. Revista da Sociedade Brasileira de Medicina Tropical, 42: 348-350. 
Clarke, S.C.; Mclntyre, M. 1996. Modified detergent Ziehl-Neelsen technique for the staining of Cyclospora cayetanensis. Journal of Clinical Pathology, 49: 511-512.

Coimbra Jr, C.E.A. 2014. Saúde e povos indígenas no Brasil: reflexões a partir do I Inquérito Nacional de Saúde e Nutrição Indígena. Cadernos de Saúde Pública, 30: 855-859.

Escobar-Pardo, M.L.; Godoy, A.P.O.G.; Machado, R.S.; Rodrigues, D.; Fagundes-Neto, U.; Kawakami, E. 2010. Prevalência de parasitoses intestinais em crianças do parque indígena do Xingu. Journal of Pediatrics, 86: 493-496.

Genaro, O.; Ferraroni, J.J. 1984. Estudo sobre a malária e parasitoses intestinais em indígenas da tribo Nadëb-Maku, Estado do Amazonas, Brasil. Revista de Saúde Pública, 18: 162-169.

Gracey, M.; King, M. 2009. Indigenous health part 1: determinants and disease patterns. Lancet, 374: 65-75.

Hoffmann, W.A.; Pons, J.A.; Janer, J.L. 1934. The sedimentation - concentration method in Schistosomiasis mansoni. American Journal of Public Health, 9: 281-298.

Lawrence, D.N.; Neel, J.V.; Abadie, S.H.; Moore, L.L.; Adams, L.J.; Healy, G.R.; Kagan, I.G. 1983. Estudos epidemiológicos entre populaçôes ameríndias da Amazônia. Parasitoses intestinais em povoaçôes recentemente contactadas e em aculturação. Acta Amazonica, 13: 393-407.

Machado, E.R.; Costa-Cruz, J.M. 1998. Strongyloides stercoralis and other enteroparasites in children at Uberlândia city, state of Minas Gerais, Brazil. Memórias do Instituto Oswaldo Cruz, 93: $161-164$.

Martins, M.; Lacerda, M.V.G.; Monteiro, W.M.; Moura, M.A.S.; Santos, E.C.S.; Saraceni, V.; Saraiva, M.G.G. 2015. Progression of the load of waterborne and intestinal parasitic diseases in the State of Amazonas. Revista da Sociedade Brasileira de Medicina Tropical, 48 (suppl.1): 42-54.

Miranda, R.A.; Xavier, F.B.; Menezes, R.C. 1998. Parasitismo intestinal em uma aldeia indígena Parakanã, sudeste do estado do Pará, Brasil. Cadernos de Saúde Pública, 14: 507-511.

Moura, F.T.; Falavigna, D.L.M.; Mota, L.T.; Toledo, M.J.O. 2010. Enteroparasite contamination in peridomiciliar soils of two indigenous territories, State of Paraná, southern Brazil. Revista Panamericana de Salud Publica, 27: 414-422.
Neres-Norberg, A.; Guerra-Sanches, F.; Moreira-Norberg, P.R.B.; Madeira-Oliveira, J.T.; Santa-Helena, A.A.; Serra-Freire, N.M. 2014. Enteroparasitismo en indígenas Terena en el Estado de Mato Grosso do Sul, Brasil. Revista de Saúde Pública, 16: 859-870.

O'Lorcain, P.; Holland, C.V. 2000. The public health importance of Ascaris lumbricoides. Parasitology, 121: S51-S71.

Rios, L.; Cutolo, S.A.; Giatti, L.L.; Castro, M.; Rocha, A.A.; Toledo, R.F. et al. 2007. Prevalência de parasitos intestinais e aspectos socioambientais em comunidade indígena no Distrito de Iauaretê, Município de São Gabriel da Cachoeira (AM), Brasil. Saúde e Sociedade, São Paulo, 16: 76-86.

Ritchie, L.S. 1948. An ether sedimentation technique for routine stool examination. The Bulletin of the U.S. Army Medical Department, 8: 326.

Santos, F.S.; Gama, A.S.M.; Fernandes, A.B.; Reis-Junior, J.D.D.; Guimarães, J. 2010. Prevalência de enteroparasitismo em crianças de comunidades ribeirinhas do Município de Coari, no médio Solimóes, Amazonas, Brasil. Revista Pan-Amazônica de Saúde, 1: 23-28.

Santos, R.V.; Coimbra Jr., C.E.A. 2005. Cenários e tendências da saúde e da epidemiologia dos povos indígenas no Brasil. In: Coimbra Jr., C.E.A; Santos, R.V.; Escobar, A.L. (Ed.). Epidemiologia e saúde dos povos indígenas no Brasil. Editora FIOCRUZ/ABRASCO, Rio de Janeiro, p. 13-47.

Santos, R.V.; Coimbra Jr., C.E.A.; Flowers, N.M.; Silva, J.P. 1995. Intestinal parasitism in the Xavante indians, Central Brazil. Revista do Instituto de Medicina Tropical de Sáo Paulo, 37: 145-148.

Sayasone, S.; Utzinger, J.; Akkhavong, K.; Odermatt, P. 2015. Multiparasitism and intensity of helminth infections in relation to symptoms and nutritional status among children: a crosssectional study in southern Lao People's Democratic Republic. Acta Tropica, 141: 322-31.

Stephens, C.; Nettleton, C.; Porter, J.; Willis, R.; Clark, S. 2005. Indigenous peoples' health-why are they behind everyone, everywhere? Lancet, 366: 10-13.

Weatherhead, J.E.; Hotez, P.J. 2015. Worm infections in children. Pediatrics in Review, 36: 341-352.

Recebido em 18/12/2015

Aceito em 14/03/2016 